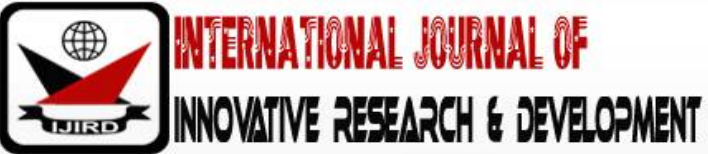

ISSN 2278-0211 (Online)

\section{Militarization of Electoral Process and Political Participation in the 2019 General Elections in Rivers State, Nigeria}

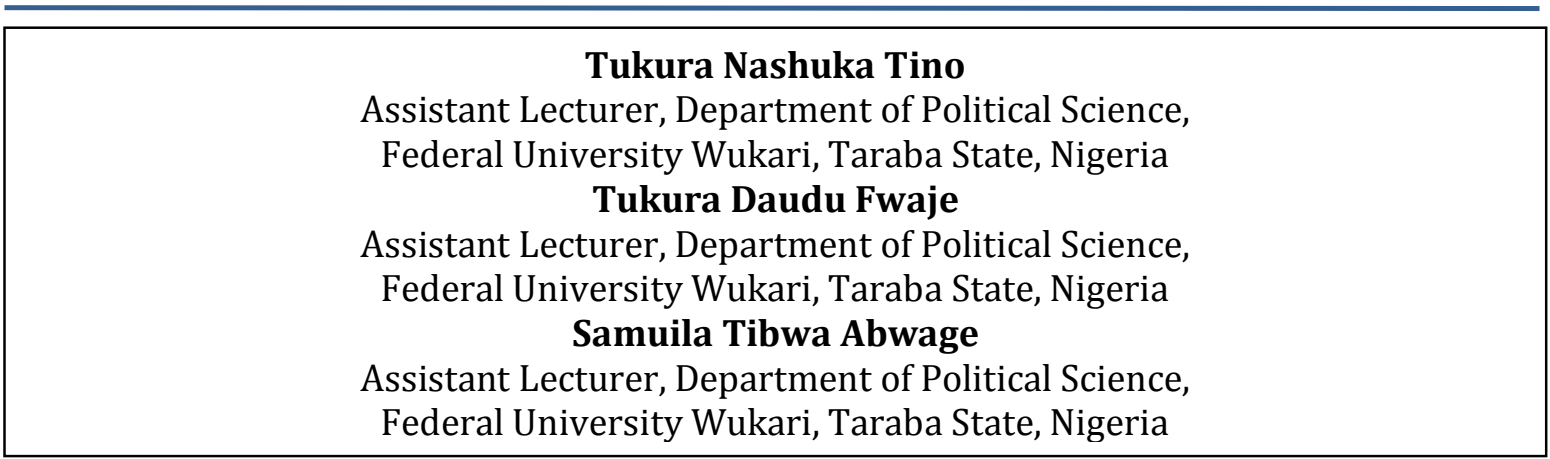

\begin{abstract}
:
Africa has encountered colossal challenges in its quest for democratization; one of which has been the militarization of politics. Though Nigeria is gradually shedding the black history of militarism that spanned the 1960s-1990s and embracing democratization, militarism still lingers, remaining a ghost that has haunted the country's democracy venture. This scenario has prompted Ntalaja to argue that democratic process in Nigeria is bedeviled by poor party politics as a result of not only excessive westernization of the concept 'democracy', but also the politicization of the higher echelon of the military profession among others. Although the 2019 general elections have come and gone, but the credibility of the entire process received a lot of criticisms based on how those allotted different roles by law and the relevant authorities conducted themselves. Amidst the raging bubbling anger among Nigerians over the involvement of military in the 2019 general elections, many political analysts dug into how due process was subverted in some states across the country during the elections. Rivers State, the oil and gas capital of Nigeria, is one of the states embroiled in controversies associated with the elections whose process was suspended and declared inconclusive by INEC due to the sheer number of military personnel on duty during the elections and the partisan role they played. This paper by employing the post-colonial state theory argues that the involvement of the military in Rivers state 2019 General Elections is a reflection of the authoritarian character of the Nigerian state. The findings revealed that military presence in Rivers state in the 2019General Elections accounts for the low voters' turnout in the state. The paper depended on documentary method and utilizes content analysis. This paper recommended among other that in spite of the non-tolerant nature and behavior of the political elites, the military of whatever status or nature be kept from being part and parcel of the electoral processes by allowing the civilian authorities to conduct and carry out the entire processes at all levels.
\end{abstract}

Keywords: Militarization, election, electoral process, political participation and rivers state

\section{Introduction}

Nigeria in 2019 has witnessed its 20th years of uninterrupted democracy. However, elections in the country's Fourth Republic which started on 29th May, 1999 have always been marred by electoral violence raging from rigging, snatching of ballot boxes, thuggery, assignation and kidnapping of electoral officers and election observers in addition to the increasing insecurity which have continued to plague some parts of the country. Although the 2019 general elections have come and gone but the controversies surrounding the conduct of the elections and most especially, the militarization of the process have been greeted with public debate (Christopher, 2019).Since the return to civil rule in May 29, 1999, Nigerians have not experienced militarization of elections as was seen in the 2019 general elections. The military was used by political class to propagate violence and rigging in an attempt to influence the outcomes of the elections to their advantage. According to Christopher (2019) there were reports that the army blocked domestic and international observers from monitoring the conduct of the elections and also barred party agents from observing collation of results at some collation centers which has questioned the professionalism and constitutional obligation of the military. In the midst of the intense bubbling anger by Nigerians over the involvement of military in the 2019 general elections, political analysts have attempted to explain how due process was subverted in some states across the country during the recent elections.A fundamental pillar of democracy is the rule of law; therefore, disrespect for the law breeds a gradual descent to chaos. The state is obligated to ensure that voters who are sovereign can exercise their franchise freely, unmolested and undisturbed; voters are also allowed to have unrestrained freedom in exercising their franchise under the provisions of the Electoral Act 
2010 (as amended) Godwin, et al (2019). It is important to note that the Act of Parliament outlaws the use of force or violence during elections, a provision, which a number of political observers and analysts said the deployment of military personnel during the 2019 elections tend to undermine. Although the military and the apologists of militarization of electoral process have attempted to validate the militarization of the 2019 general elections arguing that the military acted within the ambits of the law grounded on the rules of engagement of the military in operations and citing insecurity as reason for the deployment of military to elections. However, the Supreme Court judgment in 2005 on the issue of military involvement in election duties invalidates the military assertion of acting within the ambits of law based on the rules of engagement. The Supreme Court had on different occasions and suits, ruled unambiguously that the military had no role to play in the conduct of elections. Its interpretations of the law and resultant decisions on cases bordering on the deployment of military for election duties were icing on the cake on the judgment of the Court of Appeal while arbitrating on several election matters. Professionally, the military has no business in providing extra security on Election Day because the constitutional responsibility of the military is to defend the nation against external aggression and quell internal insurrection.

Scholars such as Olaniyan and Amao (2015) argued that the deployment of the military during elections in Nigeria between 2007 and 2014, has received criticism and public rage in the country. Notably, were the governorship elections in Edo and Ondo States in 2012, Anambra State in 2013, and the Ekiti and Osun governorship elections in 2014. Rather than depending on the police to maintain internal security needed during the gubernatorial elections in the above-named states as provided for in section 215(3) of the 1999 constitution of Federal Republic of Nigeria (as amended), the Nigerian government deployed large contingent of military to ensure peaceful conduct of the elections. According to Olokor (2019), the Independent National Electoral Commission (INEC) stated that the military was used to intimidate and unlawfully arrest its staff during the recent governorship election held on March 9, 2019, in Rivers state and posited that the commission also frowned at the partisan role played by the military and armed mobs in Rivers State through its National Commissioner and Chairman of its Information and Voter Education Committee, Mr. Festus Okoye who stated that collation centres were invaded by some armies and armed mobs resulting in the intimidation and unlawful arrest of election officials, thereby disrupting the collation process and consequent suspension of the process by INEC. Oyeyipo and Oluku (2019) stated that one of the 2019 election observers Integrity Friends for Truth and Peace Initiative (TIFPI) in their reports on the elections observed that there was involvement and interference by the Army and other men in security uniforms in elections in Imo, Rivers, Zamfara, Kaduna, AkwaIbom, Edo, Kogi, Lagos, Kaduna, Kano and Ogun states where some politicians deployed their personal security attaches to disrupt elections on various fronts. It was also reported by the observer group that there was used of fake militaries and infiltration of some of the security formations in the elections. It is against this backdrop that this paper argues that the deployment of the military during the 2019 General Elections in Rivers state accounts for the low voters' turnout in the state.

\section{Conceptualization Issue}

\subsection{Militarization}

Militarization like other concept in political science does not lend itself to a universally acceptable definition. Several scholars have defined the concept from their epistemological foundations. Accordingly, Bonn International Center for Conversion (2019) postulates that militarization is a difficult term with many interpretations and definitions. From a qualitative perspective, militarization means to gear a state or a society toward the needs of a military environment or to subject a community to military requirements. In quantitative terms, militarization means that a state or an area is furnished with military personnel or military equipment and the necessary funds for that purpose. BICC (2019) also defines militarization as the process by which a society organizes itself for military conflict and violence. Farzana (2005 in Okechukwu et al, 2019) submits that militarization as a process normalizes the use of coercive structures and practices in all forms of social interaction and institutions. For him, it is an ideology that privileges coercion, glorifies military power in the name of state security, institutionalizes methods of overlooking the due process of law, and criminalizes dissent in the interest of national security (Farzana, 2005).

Uyangoda (2005 cited in Okechukwu et al, 2019) sees militarization as the use of military power and force to solve political and social problems: it implies not just the deployment, threat or use of force, but also defining political and social conflicts problems that can be put down by force.

\subsection{Political Participation}

In the social sciences especially in the noble discipline of political science, the term political participation is frequently used to describe an action taken by a citizen to influence the outcome of a political issue. It is the involvement of the citizens in the political system. Adelekan (cited in Falade, 2014) defined political participation as the process through which the individual plays arole in the political life ofhis society and has the opportunity to take part in deciding what common goals of the society are and the best way of achieving these goals. According to Akamare (cited in Falade, 2014) political participation is an aspect of political behaviour and it focuses on the way in which individuals take part in politics. It is a voluntary activity and one may participate directly or indirectly. The various ways by which the people can be involved in the political system include voting, holding of political positions, protest, formulation of policies, community activities and other civic engagements. According to Awolowo and Aluko (2010), the essence of political participation in any society, either civilized or primitive, is to seek control of power, acquisition of power and to influence decision making. Political participation as one of the fundamental requirements of democratic governance is a means of contributing one's quota to the political system and overall development of the nation (Falade, 2014). This is why Adelekan (2010) quoted in 
Falade (2014) emphasizes that ideally, democracy means individual participation in the decisions that involves one's life. To him, in a democratic system, there is the necessity for the citizenry to be fully involved in the democratic procedures of the choice of rulers and effective communication of the public policies and attitudes. Any claim to democratic regime or state must essentially embrace a high degree of competitive choice, openness, and enjoyment of civic and political liberties and political participation that involves all groups of the society (Arowolo \& Aluko, 2010). It is pertinent therefore, to note that the extent to which individuals participate in the political system differs from person to person.

\subsection{Theoretical Framework}

This paper employs the theory of the post-colonial state developed by Hamza Alavi in 1972 and advanced by third world scholars like Ake (1981), Ekekwe (1986), Ibeanu (1988), Nnoli (1986), Idode (1989), and Mbah (2011) among others. The theory assumes that the nature, character and institutional framework that has informed and characterized the state has its foundation in a colonial state and its concomitant concept 'imperialism'. Scholars of this theory argue that connected with the dwindling capital penetration in the economy is intense political competition to control the bureaucratic or administrative state apparatus. To this theory, the intensifying political competition for state power coincides with the socio-economic competition. Forlfesinachi (2006) the relative autonomy of the state depends on the management of government institutions of the state by political leadership. Ake (1973) submits that a relative autonomy state does not limit itself to supervisory or regulatory role and is thus compromised to an extent that instead of rising above class struggle is deeply immersed in it.Ake (1981) also argues that by involving the state so intimately in the class struggle and by increasing the state power, the blurring of the distinction between the ruling class and the state is reinforced, and the government collapses into the ruling class reinforcing the authoritarianism of the hegemonic faction of the bourgeoisie. Therefore, elections are merely a system for political ideological reification of the hegemony and power of the dominant class or a system of acculturation through which dominant ideologies, political practices and beliefs are reproduced (Adejumobi, cited in Anichie, 2017). Within the context of class differentiations and inequalities, therefore, the theory posits that the very relative autonomy of the state means that political rights as enshrined in elections present little or no choice to the dominated class as the choice of candidates are agenda wavers among members of dominant class (Anichie, 2017). Consequently, Ake (1995) stated that the implication of this is a dissociation of voting g from choice and rights from the exercise of political power. What this means therefore, is that elections cannot facilitate or foster political accountability, responsiveness and democracy, which is why Ogban-Iyam (quoted in Anichie, 2017) argues that this form of electoral democracy practice in Nigeria does not translate to popular democracy and hence could only be termed 'electocracy'.

The theory also posited that because of the weak and fragile economic base of the class that inherited the postcolonial state, the state invariably became a major instrument of capital acquisition, investment and development. Hence, the acquisition and exercise of state power serves as a means of investment for those who control the state (Ake, 1981, Mbah, 2011). Ake (1981) further argues that the very limited autonomy character of the state means that the state is institutionally constituted in such a way that it enjoys limited independence from the social classes, particularly the hegemonic class, and therefore, is immersed in the class struggle that goes on in the society. The theory further assumes that power struggle in the state is akin to life and death which is seen as a zero-sum game where winner takes all.

The fundamental assumption of the theory of the post-colonial state is on understanding the nature, structure, history, composition and character of the Nigerian state in order to analyze the dynamics of political development and processes within the state, and these dynamics include militarization of electoral process and political participation in Rivers state. Within this background, therefore, it is plausible to argue that the struggle for state power are very high and often assume a zero-sum game approach. The very limited autonomy of the state leads to an exclusive politics articulated in the struggle for state power based on efficiency norms rather than legitimacy norms, democratic principle, the triumph of the vicious over virtuous circle, centralization of power; imposition of domination and political control and alienation of leaders from their masses; and the deployment of thugs in the exercise of power are all hallmarks of the relative autonomy state.

\subsection{Application of the Theory}

From the foregoing analysis, the relationship between militarization of electoral process and political participation in the 2019 general elections in Rivers state is better explained in light of the theory of post-colonial state. This framework unravels the hidden relation that explain how the deployment of military to Rivers state elections, weak, very limited autonomy of the state, and quest for power character of the Nigerian state with high degree of lack of democratic principle, disregard to the Country's constitution and the authoritarian character of the Nigerian are fundamentally responsible for the low voters turnout in the 2019 general elections in Rivers state. This is basically so because the struggle for power is regarded as a means of primitive accumulation of wealth for those who control the state.

\section{Discussion and Findings}

One of the implications of militarization of election in Nigeria's democracy is voter's apathy. There was wide spread apathy on the side of Nigeria voters during the 2019 General Elections and as Olukosi (2019) stated, militarizing the Nigerian elections contributed to low voter turnout. Because of the pattern of aggression in Nigerian militaries, most electorates dread them to the extent that they do everything to avoid them. Out of the 82,344,107 registered voters, only 29,364,209 representing 36\% were accredited for the 2019 presidential election in Nigeria, total votes cast stood at $28,614,190$, of which $27,324,583$ were valid while 1,289,607 votes were rejected. In the 2015 presidential election in Nigeria, of the $67,422,005$ registered voters, $31,756,490$ representing $47 \%$ were accredited, a total of $29,432,083$ votes 
were cast, of which 28,587,564 were valid and 844,519 votes were voided. The results above show that the rate ofturnout in the 2019 General Elections (36\%) is lower compared with the 47\% that was recorded in the 2015 General Elections. Rivers state which is our study area, has 23 local government area, with a total of 319 electoral wards and 4,442 polling units (Adebayo, 2019). In Rivers state,militarization of elections led to low voters' turnout in the 2019 presidential and governorship elections in the state compared to the turnout in 2015 general elections. For instance, out ofthe 2, 324, 300 registered voters in Rivers state, 1,555,462 representing 70\% were accredited for the 2015 presidential election, while in 2019 , of the 3, 125,278 registered voters in Rivers state, only 678,167 representing $21 \%$ were accredited for the 2019 presidential election. Similarly, for the 2015 governorship election in Rivers state, of 2,324,300 registered voters, $1,228,614$ representing $53 \%$ were accredited, while in 2019 of the 3,125,278 registered voters, only 1,130,445 representing $36 \%$ were accredited for the 2019 governorship election in Rivers state

\begin{tabular}{|c|c|c|c|c|}
\hline $\begin{array}{c}\text { No of Registered } \\
\text { Voters }\end{array}$ & $\begin{array}{c}\text { No of Accredited } \\
\text { Voters }\end{array}$ & Total Valid Votes & Rejected Votes & Total Votes Cast \\
\hline $2,324,300$ & $1,643,409$ & $1,555,462$ & 19,306 & $1,574,768$ \\
\hline
\end{tabular}

Table 1: Showing Total Number of Registered Voters and Votes Cast for the 2015 Presidential Election in Rivers State

Source: Author's Compilation with Data Generated from Isine (2015)

Of the 2, 324, 300 registered voters in Rivers state, 1,555,462 representing 70\% were accredited for the 2015 presidential election; a total of 1,574,768 votes were cast, of which 1,555,462 were valid and 19, 306 votes were rejected.

\begin{tabular}{|c|c|c|c|c|}
\hline $\begin{array}{c}\text { No of Registered } \\
\text { Voters }\end{array}$ & $\begin{array}{c}\text { No of Accredited } \\
\text { Voters }\end{array}$ & Total Valid Votes & Rejected Votes & Total Votes Cast \\
\hline $2,324,300$ & $1,228,614$ & $1,172,535$ & 14,760 & $1,187,295$ \\
\hline
\end{tabular}

Table 2: Showing Total Number of Registered Voters and Votes Cast for the 2015

Governorship Election in Rivers State

Source: Author's Compilation with Data Generated from Isine (2015)

In the 2015 Governorship election in Rivers State, a total number of 2,324,300 voters were registered, 1,228,614 representing $53 \%$ were accredited, a total of 1,187,295 votes were cast, of which 1,172,535 votes were valid while 14,760 votes were rejected.

\begin{tabular}{|c|c|c|c|c|}
\hline $\begin{array}{c}\text { No of Registered } \\
\text { Voters }\end{array}$ & $\begin{array}{c}\text { No of Accredited } \\
\text { Voters }\end{array}$ & Total Valid Votes & Rejected Votes & Total Votes Cast \\
\hline $3,125,278$ & 678,167 & 642,165 & 24,420 & 666,585 \\
\hline
\end{tabular}

Table 3: Showing Total Number of Registered Voters and Votes Cast for the 2019

Presidential Election in Rivers State

Source: Compiled by the Researcher with Data from Adebayo (2019)

Of the 3,125,278 registered voters in Rivers state, only 678,167 representing 21\% were accredited for the 2019 presidential election, a total of 666, 585 votes were cast, of which 642,165 were valid and rejected votes stood at 24,420. It should be noted that the increased in number of registered voters from 2, 324, 300 to 3, 125, 278 in Rivers state between 2015 and 2019, was as a result of the continuous voter's registration exercise by the Independent National Electoral Commission (INEC).

\begin{tabular}{|c|c|c|c|c|}
\hline $\begin{array}{c}\text { No of Registered } \\
\text { Voters }\end{array}$ & $\begin{array}{c}\text { No of Accredited } \\
\text { Voters }\end{array}$ & Total Valid Votes & Rejected Votes & Total Votes Cast \\
\hline $3,125,278$ & $1,130,445$ & $1,102,803$ & 21,037 & $1,123,840$ \\
\hline
\end{tabular}

Table 4: Showing Total Number of Registered Voters and Votes Cast for the 2019 Governorship Election in Rivers State

Source: Compiled by the Researcher with Data from Adebayo (2019)

Out of the 3,125,278 registered voters, only 1,130,445 representing 36\% were accredited for the 2019 governorship election in Rivers state, 1,123,840 votes were cast, of which 1,102,803 were valid, and 21,037 were voided.

\begin{tabular}{|c|c|c|c|}
\hline Presidential Elections & $\begin{array}{c}\text { No of Registered } \\
\text { Voters }\end{array}$ & $\begin{array}{c}\text { No of Accredited } \\
\text { Voters }\end{array}$ & Total Votes Cast \\
\hline 2015 & $2,324,300$ & $1,643,409$ & $1,574,768$ \\
\hline 2019 & $3,125,278$ & 678,167 & 666,585 \\
\hline
\end{tabular}

Table 5: Voters' Turnout in the 2015 and 2019 Presidential Elections in Rivers State Compared

Source: Author's Compilation with data from INEC (2015\& 2019) 
The result from the table above shows that voters turnout decreased from 1,643,409 representing $70 \%$ in 2015 presidential election in Rivers state to 678,167 representing $21 \%$ in 2019 election, while total votes cast decreased from $1,574,768$ in 2015 presidential election to 666,585 , which was due to the deployment of military to Rivers election in 2019.

\begin{tabular}{|c|c|c|c|}
\hline Presidential Elections & $\begin{array}{c}\text { No of Registered } \\
\text { Voters }\end{array}$ & $\begin{array}{c}\text { No of Accredited } \\
\text { Voters }\end{array}$ & Total Votes Cast \\
\hline 2015 & $2,324,300$ & $1,228,614$ & $1,187,295$ \\
\hline 2019 & $3,125,278$ & $1,130,445$ & $1,123,480$ \\
\hline
\end{tabular}

Table 6: Voters' Turnout in the 2015 and 2019 Governorship Elections in Rivers State Compared Source: Author's compilation with data from INEC (2015 \& 2019)

From the result on the table above, voters turnout decreased from 1,228,614 representing 53\% in the 2015 governorship election in Rivers State to 1,130,445 representing 36\% in 2019 in spite of the significant increase in number of registered voters from 2,324,300 in 2015 to 3,125,278 in 2019 following the continuous voters registration exercise by INEC, while total votes cast decreased from 1,187,295 to 1,123,480 in 2019. Again, the decreased in the percentage of voters' turnout from 53\% in 2015 to $36 \%$ in 2019 governorship elections in Rivers state is caused by militarization of the electoral process.

\begin{tabular}{|c|c|c|c|c|}
\hline Elections & $\begin{array}{c}\text { Presidential } \\
\mathbf{2 0 1 5}\end{array}$ & $\begin{array}{c}\text { Governorship } \\
\mathbf{2 0 1 5}\end{array}$ & $\begin{array}{c}\text { Presidential } \\
\mathbf{2 0 1 9}\end{array}$ & $\begin{array}{c}\text { Governorship } \\
\mathbf{2 0 1 9}\end{array}$ \\
\hline $\begin{array}{c}\text { Registered } \\
\text { Voters }\end{array}$ & $2,324,300$ & $2,324,300$ & $3,125,278$ & $3,125,278$ \\
\hline $\begin{array}{c}\text { Accredited } \\
\text { Voters }\end{array}$ & $1,643,409$ & $1,228,614$ & 678,167 & $1,130,445$ \\
\hline Valid Votes & $1,555,462$ & $1,172,535$ & 642,162 & $1,102,803$ \\
\hline Rejected Votes & 19,306 & 14,760 & 24,420 & 21,037 \\
\hline $\begin{array}{c}\text { Total Votes } \\
\text { Cast }\end{array}$ & $1,574,768$ & $1,187,295$ & 666,585 & $1,123,480$ \\
\hline
\end{tabular}

Table 7: Voting Summary in 2015 and 2019 Presidential and Governorship Elections in Rivers State Source: Compiled by the author with data from INEC (2015 \& 2019

\section{Conclusion and Recommendations}

Military involvement in the 2019 General Elections in some states like Imo, Kaduna, AkwaIbom, Kogi, Zamfara, Lagos, Ogun and Rivers state which is the oil and gas capital of Nigeria does not only account for low level of voters' participation in these states, but also undermined the credibility of the entire electoral process. The findings revealed that military presence prevented a number of voters from coming out to vote, thereby leading to high level of voting apathy, intimidation, tension, violence and killings recorded in some states particularly Rivers state. Fundamentally, militaries rank and file, are expected to be isolated from partisan politics and should therefore, not engage in activities capable of threatening and truncating Nigeria's democracy project. Many Nigerians are not committed to the electoral process and other political engagements because the Nigerian political system and act of governance do not encourage mass participation. Consequently, the political culture of violence, intimidation, manipulation, sentiments, money politics, ignorance, corruption, deception and apathy that characterize the Nigerian political system has continue to threatened the country's democracy project.

\section{Recommendations}

On the basis of the findings, this paper recommended that:

- Elections in Nigeria should be demilitarized and our electoral process should undergo urgent reforms. The military should see elections as an entirely civic exercise and military of whatever status or nature be kept from being part and parcel of the electoral processes.

- The Nigeria Police and its sister agencies should be trained and retrained on how to tackle election related violence and crime before, during and after elections with high degree of professionalism.

- It is appropriate that legislation be made to restrict the military to the barracks on elections day.

- The military should concentrate on their core and constitutional obligation of protecting Nigeria from external aggression and internal insurrection.

- Government should consider strengthening the capacity of the Nigerian police to enable it discharge its constitutional obligation of maintaining internal security in the country, particularly during and after the conduct of elections, which are largely civic by nature and orientation. 


\section{References}

i. Adebayo, T.H. (2020, April 24). Atiku Wins Rivers as Collation Ends in Chaos. Premium Times online

ii. Adelekan, A.T. (2010) Effects of Role-Play and Moral Dilemma Techniques on Secondary School Students' Achievement in and Attitude to Political Education. An Unpublished Ph.D. Thesis, Faculty of Education, University of Ibadan, Ibadan, Nigeria

iii. Ake, C. (1973) Explaining Political Instability in New States, Journal of Modern African Studies 2 (3), pp.351-359.

iv. Ake, C. (1981) Political Economy of Africa. Ibadan: Longman Nigeria Ltd.

v. Ake, C. (1995) Is Africa Democratizing? in O. Mimiko (ed) Crises and Contradictions in Nigeria's Democratization Programme, 1986-1993, Akure: Stebak Ventures.

vi. Alavi, H. A (1972) The State in Post-Colonial Societies Pakistan and Bangladesh. New Left Review,1 (74), pp.5981

vii. Aniche, E.T. (2017) The 'David and Goliath' and the 2015 Elections Outcome in Nigeria. From the Opposition to the Ruling Party. Journal Indexing and Metrics 10(1) Google Scholar

viii. Awolowo, D. and Aluko, F.S. (2010) Women and Political Participation in Nigeria. European Journal of Social Sciences14 (4), 581-593

ix. Christopher, P. (2019). Militarization of 2019 Elections: The Way Forward. Platinum Nigeria March 17

x. Falade, D.A. (2014). Political Participation in Nigeria Democracy: A Study of Some Selected Local Government Areas in Ondo State. Global Journal of Human-Social Sciences, 14(8), pp.17-23

xi. Godwin, O., Gbadamosi, H., Maruf, O. and Babajide, J. (2019). Militarization of Elections: In Whose Interest? Tribune March 17

xii. Ifesinachi, K. (2000) Military Rule and the Crisis of Development in Nigeria in E. Anugwom, et al (eds) The Social Science Issues and Perspectives, Nsukka: Fulladu Publishing Company.

xiii. INEC (2015) Total Number of Registered Voters and Collected PVCs for the 2015 General Elections

xiv. INEC (2019) 2019 Polls: Voters Turnout rises in 19 States. Daily Trust February 28

XV. INEC (2019)Total Number of Registered Voters and Collected PVCs for the 2019 General Elections

xvi. Isine, I. (2020, April 13). INEC Declares Wike Governor-Elect in Rivers Amidst Protest by APC, LP. Premium Times online

xvii. Isine, I. (2020, March 30). PDP Wins Disputed Presidential Election in Rivers. Premium Times online

xviii. Mbah, P. (2011) Party Defection and Democratic Consolidation in Nigeria, 1999-2009. Afro Asian Journal of Social Sciences, 2(2), pp. 1-21.

xix. Nnoli, O. (1986) Introduction to Politics. Lagos: Longman.

xx. Ogban-Iyam, O. (2005) .Social Production and Reproduction, Societal Conflicts and the Challenge of Democracy in Nigeria. University of Nigeria Journal of Political Economy 1(1), pp.1-51.

xxi. Okechukwu, A.T., Chukwuka, O.M., and Chikwado, N.K. (2019). Militarization, Electoral Violence and 2019 General Elections in Nigeria. International Journal of Scientific and Research Publications, 9(10), pp.84-92

xxii. Olaniyan, A., and O. B. Amao, O.B (2015) Election as Warfare: Militarization of Elections and the 'Cchallenges of Democratic Consolidation International Affairs Forum Spring, pp. 70-81

xxiii. Olokor, F. (2019). Rivers Election: Soldiers, Armed Gangs used to Intimidate, Arrest our Staff. Available at https://punchng.com/rivers-election-soldiers-armed-gangs-used-'to intimidate arrest-our-staff-says-inec

xxiv. Sahara Reporters (2019, April 3). Breaking: Wike Wins Rivers Governorship Election by an Insane Margin 